12. Horst RL, Littledike ET, Riley JL, Napoli JL. Quantitation of vitamin $\mathrm{D}$ and its metabolites and their plasma concentrations in five species of animals. Anal Biochem 1981;116:189-203.

13. Hollis BW, Frank NE. Solid phase extraction system for vitamin $D$ and its major metabolites in human serum. J Chromatogr 1985;343:43-9.

14. Hollis BW, Napoli JL. Improved radioimmunoassay for vitamin D and its use in assessing vitamin D status. Clin Chem 1985;31:1815-9.

15. Hollis BW. Comparison of equilibrium and disequilibrium assay conditions for ergocalciferol, cholecalciferol and their major metabolites. J Steroid Biochem 1984;21:81-6.

16. Hollis BW, Pittard WB. Evaluation of the total fetomaternal vitamin D relationships at term: evidence for racial differences. J Clin Endocrinol Metab 1984;59:652-7.

17. Calvo M, Ena JM. Relations between vitamin $D$ and fatty acid binding properties of vitamin D-binding protein. Biochem Biophys Res Commun 1989;163:14-7.

18. Williams MH, VanAlstyne EL, Galbraith RM. Evidence of a novel aseociation of unsaturated fatty acids with $G_{c}$ (vitamin D-binding protein). Biochem Biophys Res Commun 1988;153: 1019-24.

19. Bouillon $R$, Van Herck E, Jans I, Tan BK, Van Baelen $H$, DeMoor P. Two direct (nonchromatographic) aseays for 25-hydroxyvitamin D. Clin Chem 1984;30:1731-6.

20. Chapuy MC, Arlot ME, DuBoeuf F, Bron J, Crouset B, Arnaud $S$, et al. Vitamin $D_{3}$ and calcium to prevent hip fractures in elderly women. N Engl J Med 1992;327:1637-42.

21. Gloth FM, Tobin JD, Sherman SS, Hollis BW. Is the recommended daily allowance for vitamin $D$ too low for the homebound elderly? J Am Geriatr Soc 1991;39:137-41.

\title{
How and How Long to Store Urine Samples before Albumin Radioimmunoassay:
} A Practical Response

\author{
Ottavio Giampietro, Giuseppe Penno, Aldo Clerico, ${ }^{1}$ Lorella Cruschelli, and Mauro Cecere
}

We used three study protocols to check the dependence of albumin stability, measured by an RIA, on different temperatures, durations, and materials (i.e., assay tubes) of urine storage. Albumin values obtained for samples stored in three types of assay tubes (glass, polystyrene, and polypropylene) throughout the 2 months of the first (prospective) protocol were superimposable. The 24-h storage of six urine samples at room temperature or at $4^{\circ} \mathrm{C}$, as well as $72-h$ storage at $4^{\circ} \mathrm{C}$, did not affect the albumin measurement by RIA. After 2 months of storage of these same six urine samples at $-20^{\circ} \mathrm{C}$, there was still no albumin decrease. A significant albumin decrease occurred (a mean of $\sim 5 \%$ per year, throughout the range of albumin concentrations tested) when samples stored at $-20^{\circ} \mathrm{C}$ were reassayed by RIA after $\geq 2$ years (second protocol, retrospective). Finally, 3 of 21 (14.3\%) urine pools stored at $-20^{\circ} \mathrm{C}$ for various periods (4-21 months) showed a significant albumin loss after storage; the time of storage as well the decrement rates of these 3 pools differed from each other (third protocol, retrospective). Short- and medium-term (2-6 months) freezing of urine samples at $-20^{\circ} \mathrm{C}$ does not significantly affect the stability of immunoreactive albumin. For longer preservation periods, storage of urine samples at $-70^{\circ} \mathrm{C}$ may be preferable.

Indoxing Terms: external quality control - albuminuria - diabotos mellitus - variation, source of - sample handing

Cattedra di Malattie del Metabolismo, Istituto di Clinica Medica 2", Via Roma 67, 56100 Pisa, Italy.

1 Istituto di Fisiologia Clinica del CNR, Universita degli Studi di Pisa, Pisa, Italy.

Received June 29, 1992; accepted September 28, 1992.
Measurement of urinary albumin excretion in the range of 20-200 mg/day, so-called microalbuminuria, is used to evaluate kidney involvement in people with diabetes mellitus $(1,2)$. Indeed, diabetic renal disease may be reversible by tight metabolic control, if detected early (1). Accordingly, screening to determine urinary albumin excretion has become a frequent part of diabotes care $(1,2)$.

Contradictory evidence (2-9) has been reported about the effect of specimen storage conditions on the results of these assays. Albumin in urine has been stated to be stable at room temperature for several hours and for a few weeks at $4^{\circ} \mathrm{C}$ without added preservative, which implies that urine samples can be stored for a relatively short time (from hours to some days) at $4^{\circ} \mathrm{C}$ until assay (2). However, epidemiological and (or) multicenter studies require that several samples be collected, stored for long periods (from several months to some years), and eventually shipped to the laboratory before the assay. Hence, storage conditions such as room temperature or $4{ }^{\circ} \mathrm{C}$ are not suitable; instead, freering the urine samples seems more appropriate. Some authors claim that storage of samples at $-20^{\circ} \mathrm{C}$ for determination of urinary albumin excretion by laser immunonephelometry (5) or RIA (7) yields falsely low results, so that freexing urine samples is not suitable. Others $(3,8)$, like us $(4,6$, 9 ), are of the opinion that freexing urine samples at $-20^{\circ} \mathrm{C}$ (or $-70^{\circ} \mathrm{C}$ ) does not in itself affect the albumin assay, and thus recommend storing specimens at $-20^{\circ} \mathrm{C}$ (or $-70^{\circ} \mathrm{C}$ ) if the assay cannot be performed within a few days (2-3 days at most).

To determine the best way to stabilize the albumin in urine until assay, we stored under different conditions and for different periods a large number of urine samples and pools treated in various ways. 
Matorlals and Mothods

RIA of Urinary Albumin

We measured urinary albumin with a commercial RIA (Albumin RIA 100; Pharmacia AB, Uppsala, Sweden) in which purified human serum albumin (HSA) is the standard, ${ }^{125}$ I-labeled HSA is the tracer, and the antiserum is specific for HSA. The bound and the free phases were separated by a solid-phase system (antirabbit IgG, raised in sheep, bound to Sepharose), and the standard curve was prepared with solutions containing known amounts of purified HSA. The analytical characteristics of this RIA have been reported in detail (10). The assay was not significantly subject to interference from bovine serum albumin, transferrin, or human immunoglobulins.

The RIA was performed according to the manufacturer's instructions. In brief, we added to all tubes $50 \mu \mathrm{L}$ of the standard solutions or urine samples, $50 \mu \mathrm{L}$ of the tracer solution ( $\sim 30000-40000$ counts/min of ${ }^{125} \mathrm{I}$-labeled HSA), and $2.0 \mathrm{~mL}$ of anti-HSA antiserum reagent; mixed; and then incubated the samples for $1 \mathrm{~h}$ at room temperature $\left(18-22^{\circ} \mathrm{C}\right)$. After centrifugation $(1500 \times g$ for $10 \mathrm{~min}, 4^{\circ} \mathrm{C}$ ), the supernates were aspirated and discarded, and the radioactivity of the precipitates was counted in a well-type gamma counter.

The mean limit of detection of this RIA was 0.29 (SD $0.12) \mathrm{mg} / \mathrm{L}(n=40)$. The mean $(n=40)$ within-assay imprecision profile and the mean RIA standard curve are shown in Figure 1. The working range [the concentration range of albumin that was measured with an imprecision (CV) <10\%] was 2-62 $\mathrm{mg} / \mathrm{L}$; consequently, the urine samples with albumin concentrations $\geq 60 \mathrm{mg} / \mathrm{L}$ were reassayed after dilution. The between-assay variability (CV) for a wide range of albumin concentrations (3.4$60.1 \mathrm{mg} / \mathrm{L}$ ) observed in 21 urine pools stored at $-20^{\circ} \mathrm{C}$ ranged between $5.6 \%$ and $27.2 \%$ (Figure 2), with a pattern similar to the within-assay imprecision profile.

All sample values were measured and the index of sensitivity, the precision profile, and quality control for the RIA were performed according to a previously described computer program $(11,12)$. The interpolation of the dose-response curve was calculated by a four-parameter logistic function (12).

\section{Urine Samples}

Urine samples were collected from healthy subjects and from normo-, micro-, and macroalbuminuric diabetic patients. First-morning, 24-h, and overnight collections were included in the study. Urinalysis and urine cultures were performed on each specimen. No preservative had been added to the urine collections, and the samples were gently mixed, but not centrifuged, before assay.

\section{Study Protocols}

We used more than one protocol to check the dependence of albumin stability on various temperatures, lengths, and materials (i.e., assay tubes) of storage.

First experimental series. Six urine samples contain-

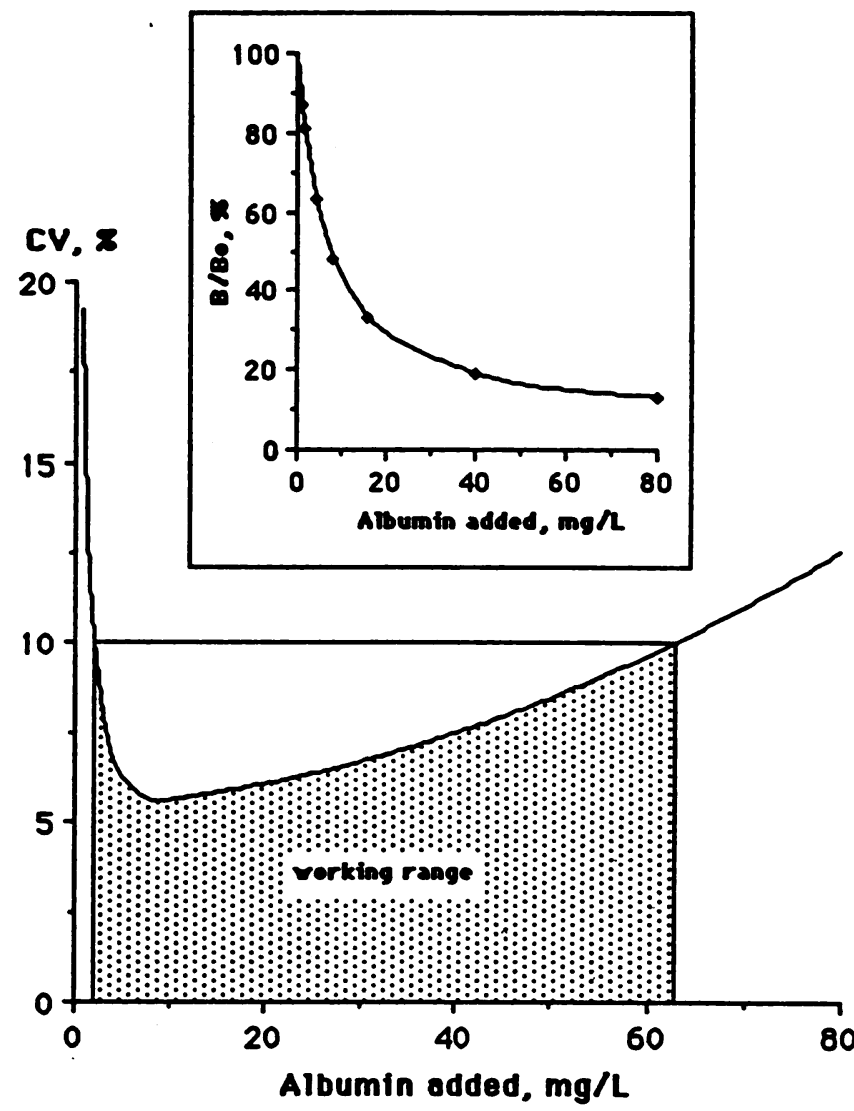

Fig. 1. Moan imprecision profile (within-assay), working range (range of albumin concentration measured with an imprecision <10\%), and mean standard curve (insert) for RIA used to measure urinary albumin in this study

ing various albumin concentrations (from 7.2 to 371.0 $\mathrm{mg} / \mathrm{L}$ ) were collected in sterile $100-\mathrm{mL}$ urine culture tubes and stored for different times (from 1 day to 2 months) at various temperatures [room temperature $\left(18-20^{\circ} \mathrm{C}\right), 4^{\circ} \mathrm{C}$, and $\left.-20^{\circ} \mathrm{C}\right]$ in several $2-\mathrm{mL}$ aliquots dispensed into three different types of assay tubes (glass, polystyrene, and polypropylene) until assay. These specimens were analyzed for albumin by the RIA in eight

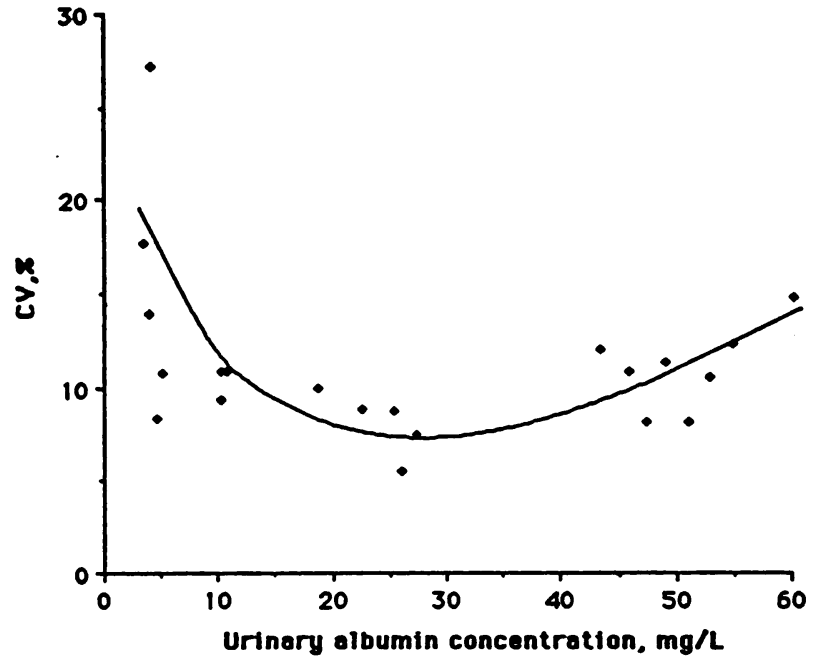

Fig. 2. Between-assay variabilities of assays of 21 urine pools with different albumin concentrations 
separate runs as follows: within $1 \mathrm{~h}$ from collection at room temperature, withdrawing urine $(50 \mu \mathrm{L})$ for the assay directly from the urine culture tubes (control sample) and from each type of assay tube; after $24 \mathrm{~h}$ (stored at room temperature and $4{ }^{\circ} \mathrm{C}$ ); after $72 \mathrm{~h}$ (stored at 4 and $-20^{\circ} \mathrm{C}$ ); and after $7,14,21,28$, and 60 days (stored at $-20^{\circ} \mathrm{C}$ ).

Second experimental series. We assayed in five separate runs two series of urine samples that had been stored at $-20^{\circ} \mathrm{C}$ : the first included 61 specimens that had been assayed 2 years before by the same RIA (albumin concentrations $2.0-344 \mathrm{mg} / \mathrm{L}$, mean $\pm \mathrm{SD}=$ $30.6 \pm 50.7 \mathrm{mg} / \mathrm{L}$ ); the second included 137 samples assayed 4-5 years before (albumin concentrations 0.3 $364 \mathrm{mg} / \mathrm{L}$, mean $\pm \mathrm{SD}=13.1 \pm 33.0 \mathrm{mg} / \mathrm{L}$ ). Most of these urine samples had been frozen and thawed more than once before the last assay.

Third experimental series. We repeatedly assayed (from 16 to 82 times in different experimental sessions; total number of assays: 692) over various periods (ranging between 4 and 21 months) 21 urine pools stored at $-20^{\circ} \mathrm{C}$ in 2-mL aliquots until assay.

\section{Statistical Analysis}

The statistical analysis was carried out by Macintosh SE and Macintosh IIsi personal computers, with use of the Stat View ${ }^{\text {Th }} \mathrm{SE}+{ }^{\text {Graphics }}$ program (1988 Abacus Concepts, Inc.). The results are expressed as mean \pm SD.

\section{Results}

First protocol. No difference lby repeated-measure analysis of variance (ANOVA), $P=0.8472$ ] was observed among results obtained with the three types of assay tubes throughout the 2 months of the experiment (Figure 3).

The 24-h storage of six urinary samples at room temperature (for polystyrene tubes, $89.8 \pm 121.4 \mathrm{mg} / \mathrm{L}$ ) and at $4^{\circ} \mathrm{C}(95.9 \pm 140.8 \mathrm{mg} / \mathrm{L})$, as well their $72-\mathrm{h}$ storage at $4^{\circ} \mathrm{C}(114.1 \pm 177.4 \mathrm{mg} / \mathrm{L})$ did not affect the measurement of albumin by RIA $(P=0.4532$ by

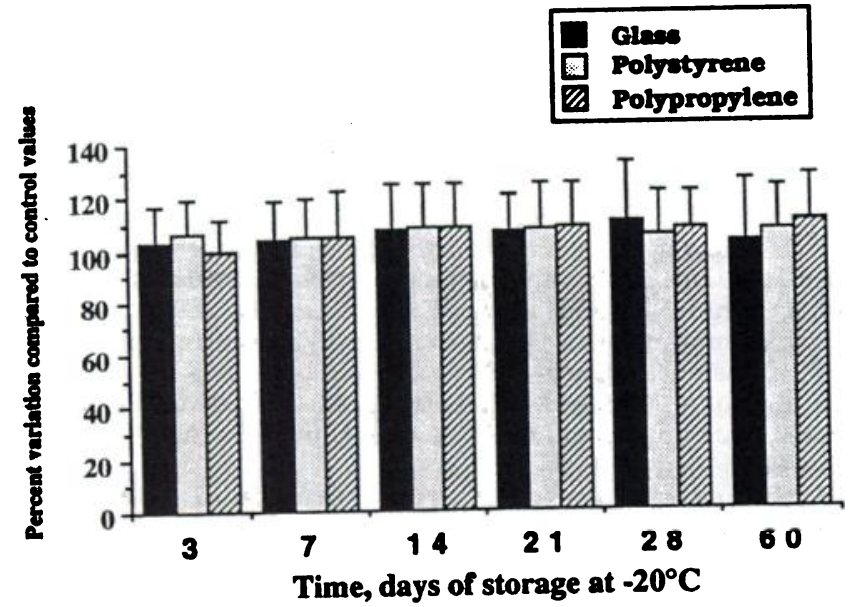

Fig. 3. First experimental series: percent variation (mean \pm SD) of albumin concentration in six urine specimens stored at $-20^{\circ} \mathrm{C}$ for $\leq 2$ months in different types of assay tubes
ANOVA), in comparison with the results determined within $1 \mathrm{~h}$ after collection $(113.1 \pm 157.5 \mathrm{mg} / \mathrm{L})$. Storage of these same six urine samples at $-20^{\circ} \mathrm{C}$ for 2 months before assay produced no significant albumin loss (by ANOVA, $P=0.8078$ ) from the initial value (Figure 3 ).

Samples stored at $-20^{\circ} \mathrm{C}$ for $\geq 2$ years. We found a significant decrease in albumin when urine samples stored at $-20^{\circ} \mathrm{C}$ were reassayed by RIA after $\geq 2$ years. The 61 urine samples frozen for 2 years had a mean decrease in albumin of 13.2\%: basal value, $30.6 \pm 50.7$ $\mathrm{mg} / \mathrm{L}$; values after 2 years, $26.5 \pm 41.2 \mathrm{mg} / \mathrm{L}(P=0.0153$ by paired $t$-test). The 137 specimens stored at $-20^{\circ} \mathrm{C}$ for 4-5 years had a mean albumin decrease of 21.8\%: basal value, $13.1 \pm 33.0 \mathrm{mg} / \mathrm{L}$; value after 4-5 years, $10.2 \pm$ $23.6 \mathrm{mg} / \mathrm{L}(P=0.0046$ by paired $t$-test). These findings indicate a mean loss of $\sim 5 \%$ per year throughout the range of albumin concentrations in urine samples frozen at $-20^{\circ} \mathrm{C}$, based on the assumption that the decrease is a linear function of the storage time.

Urine pools. Only 3 of 21 (14.3\%) pools stored at $-20^{\circ} \mathrm{C}$ showed a statistically significant albumin decrease during storage. The time of storage and the decrement rates of these three pools all differed from each other (Figure 4).

\section{Discuselon}

Here we demonstrate that the material of the storage and assay tubes - glass, polystyrene, or polypropyleno-

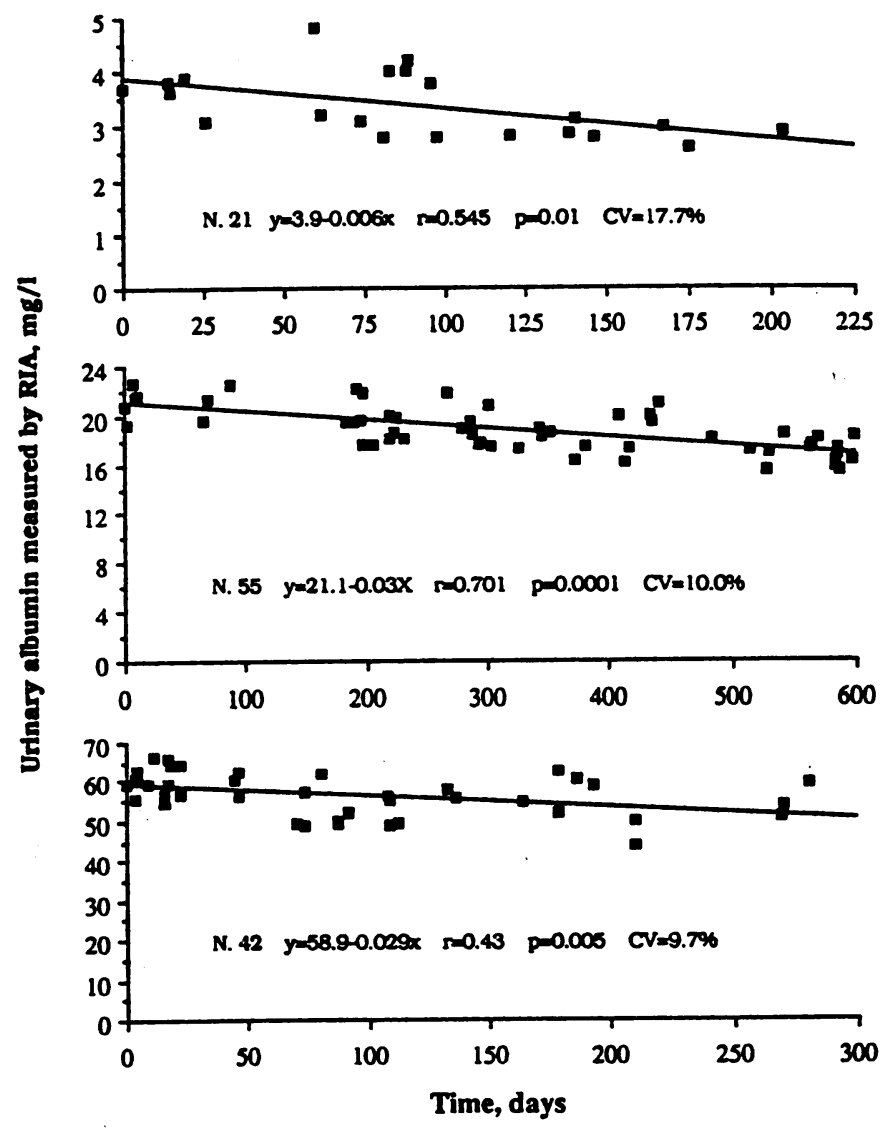

Fig. 4. Third experimental series: changes of albumin concentrations with time in the three urine pools that showed a significant albumin decrease after storage at $-20^{\circ} \mathrm{C}$ 
had no effect on urinary albumin measurement by RIA. Moreover, in our hands, albumin in urine was sufficiently stable at room temperature for $24 \mathrm{~h}$ and at $4-8{ }^{\circ} \mathrm{C}$ for at least 3 days without added preservative, thus confirming previous reports (2).

Because storing urine samples at $4^{\circ} \mathrm{C}$ for longer than 3 days is impractical, the alternative is to freeze them. To check whether storage at $-20^{\circ} \mathrm{C}$ affected albumin assayed by RIA, we analyzed results from a prospective protocol of urine storage and from two retrospective series of urine samples frozen for different long periods at $-20^{\circ} \mathrm{C}$. To minimize the effects of analytical variability and bias (especially those due to the use of different reagent lots) during the course of the study, we assayed frozen specimens in different runs by RIA. Moreover, we assayed both individual urine samples and pools in different protocols, because some authors $(13,14)$ have criticized the use of only pools in studies on the effects of time and temperature on albumin stability in urine.

The prospective protocol demonstrated that 2 months of storage at $-20^{\circ} \mathrm{C}$ did not impair the accuracy of RIA determinations of albumin in urine. These results, in conjunction with those previously provided by our group on the effects of specimen storage at $-20^{\circ} \mathrm{C}$ for $6-7$ months $(6,9)$, strikingly indicate that albumin in urine samples is not affected by freezing at $-20^{\circ} \mathrm{C}$, at least not for short- or medium-term storage $(6,9)$. What happens shortly after that is not known (no data are available). However, after 2 (and still more, after 5) years of storage at $-20^{\circ} \mathrm{C}$, a significant albumin lossalbeit of negligible clinical relevance-does occur (second protocol of this study). In fact, albumin from specimens frozen long-term at $-20^{\circ} \mathrm{C}$ decreased by $\sim 5 \%$ per year throughout the entire range of albumin concentrations. This loss is smaller than that previously reported in other, shorter studies $(5,7,8,15)$. This decrement rate of $\sim 5 \%$ per year would probably not be detectable in experiments lasting $<1$ year, because this amount of variation is usually less than the between-assay precision of the procedures routinely used to measure urinary albumin (16) (Figures 1 and 2). This indirectly confirms findings previously reported by us $(6,9)$ and by other laboratories $(3,17)$.

Because storage at $-70^{\circ} \mathrm{C}$ has been reported to be adequate to prevent substantial degradation of immunoreactive albumin in urine samples for at least 160 days, MacNeil et al. (8) recently proposed this alternative.

The third protocol of this study indicates that occasionally, in individual instances, a more rapid decrement rate of urinary albumin may occur (Figure 4), suggesting that an unpredictable rate of degradation of urinary albumin may be found among some subjects (8). At present, the reason for this is unknown, so that anticipating the behavior of the single urine albumin result in samples stored at $-20^{\circ} \mathrm{C}$ is not possible.

In conclusion, because our findings confirm that freezing urine samples does not itself significantly affect the stability of immunoreactive albumin, the question of how to treat urine samples before assay needs to be answered. If albumin cannot be measured within 1 day's storage at room temperature or within $2-3$ days of storage at $4{ }^{\circ} \mathrm{C}$, freezing urine samples at $-20^{\circ} \mathrm{C}$ for $4-6$ months is advisable and should result in no clinically significant albumin loss, regardless of the composition of the storage tubes. For longer storage, we recommend freezing the urine samples at $-70^{\circ} \mathrm{C}$.

\section{References}

1. Viberti GC, Walker JD. Diabetic nephropathy: etiology and prevention. Diabetes/Metab Rev 1988;4:147-62.

2. Rowe DJF, Dawnay A, Watts GF. Microalbuminuria in diabetes mellitus: review and recommendations for the measurement of albumin in urine. Ann Clin Biochem 1990;27:297-312.

3. Silver A, Dawnay A, Landon J, Cattell WR. Immunoassay for low concentrations of albumin in urine. Clin Chem 1986;32: $1303-6$.

4. Giampietro $O$, Miccoli $R$, Clerico A, et al. Urinary albumin excretion in normal subjects and in diabetic patients measured by a radioimmunosssay: methodological and clinical aspects. Clin Biochem 1988;21:63-8.

5. Elving LD, Bakkeren JAJM, Jansen MJH, de Kat Angelino CM, de Nobel E, van Munster PJJ. Screening for microalbuminuria in patients with diabetes mellitus: frozen storage of urine samples decreases their albumin content. Clin Chem 1989;35:30810.

6. Giampietro O, Clerico A, Cruschelli L, Penno G, Navalesi R. Microalbuminuria in diabetes mellitus: more on urine storage and accuracy of colorimetric assays [Letter]. Clin Chem 1989;35: 1560-2.

7. Osberg I, Chase HP, Garg SK, de Andrea A, Harris S, Hamilton R, Marshall G. Effects of storage time and temperature on measurement of small concentrations of albumin in urine. Clin Chem 1990;36:1428-30.

8. MacNeil MLW, Mueller PW, Caudill SP, Steinberg KK. Considerations when measuring urinary albumin: precision, substances that may interfere, and conditions for sample storage. Clin Chem 1991;37:2120-3.

9. Giampietro O, Cruschelli L, Penno G, Navalesi R, Clerico A. More on effects of storage time and temperature on measurement of amall concentrations of albumin [Letter]. Clin Chem 1991;37: 591-2.

10. Giampietro O, Clerico A, Cruschelli L, Miccoli R, Di Palma L, Navalesi R, et al. Measurement of urinary albumin excretion rate (AER) in normal and diabetic subjects: comparison of two recent radioimmunoassays. J Nucl Med Allied Sci 1987;31:321-6.

11. Pilo A, Zucchelli GC. Automatic treatment of radioimmunoassay data: an experimental validation of the results. Clin Chim Acta 1975;64:1-4.

12. Pilo A, Zucchelli GC, Malvano R, Masini S. Main features of computer algorithms for RIA data reduction. Comparison of some different approaches for the interpolation of does-response curve. $J$ Nucl Med Allied Sci 1982;26:235-48.

13. Elving LD, Bakkeren JAJM, de Kat Angelino CM. More on effects of storage time and temperature on measurement of small concentrations of albumin [Letter]. Clin Chem 1991;37:592-3.

14. Osberg I, Chase PH, Garg SK. More on effects of storage time and temperature on measurement of small concentrations of albumin [Letter]. Clin Chem 1991;37:593-4.

15. Erman A, Rabinov M, Rosenfeld J. Albumin determination in froesen urino-underestimated results. Clin Chim Acta 1988;174: 255-62.

16. Giampietro O, Penno G, Clerico A, Cruschelli L, Luechetti A, Nannipieri $M$, et al. Which method for quantifying "microalbuminuria" in diabetics? Acta Diabetol 1992;28:239-45.

17. Torffvit $O$, Wieslander J. A simplified enzyme-linked immunoeorbent assay for urinary albumin. Scand J Clin Lab Invest 1986;46:545-8. 